\title{
Transnational Law Enforcement Cooperation - Fundamental Rights in European Cooperation in Criminal Matters
}

\author{
Michiel Luchtman \\ Professor of transnational law enforcement and fundamental rights, Utrecht \\ Centre for Regulation and Enforcement in Europe/Renforce, Willem Pompe \\ Institute for Criminal Law and Criminology, Utrecht University \\ m.luchtman@uu.nl.
}

\begin{abstract}
European cooperation in criminal matters is an area full of paradoxes. This article identifies the dominant narratives that define the nature of European cooperation in criminal matters. It also aims to identify the consequences that these narratives entail for the protection of fundamental rights in that cooperation and, subsequently, for the EU's legislative agenda for the coming years. It develops a model of deeper justice integration, based on the narrative of a common European area, fostering the proper administration of criminal justice, transnational agency for individuals and fundamental rights.
\end{abstract}

\section{Keywords}

fundamental rights - Area of Freedom - Security and Justice - mutual recognition transnational enforcement - European Public Prosecutor's Office

European cooperation in criminal matters is an area full of paradoxes. Claims of national sovereignty, of regaining control over territorial borders and of the

* This article builds upon M. Luchtman, Transnationale rechtshandhaving - Over fundamentele rechten in de Europese strafrechtelijke samenwerking: The Hague: Boom Juridisch (inaugural lecture Utrecht, June 2017, in Dutch).

(C) MICHIEL LUCHTMAN, 2020 | DOI:10.1163/15718174-02801002

This is an open access article distributed under the terms of the prevailing CC-BY-NC License at the time of publication. 
fight against crime and of identity have sparked intense debates all over Europe on the added value of European integration, also in the area of security and crime control. Simultaneously, however, these debates cannot conceal the interest that is also expressed, openly or covertly, in the importance of the EU system for cooperation in criminal matters for open and resilient societies. The EU's Area of Freedom, Security and Justice (AFSJ) was also created, after all, to enable EU-states to better cope with transnational crime.

Despite the tremendous legislative activity of the last years, it is surprising to see how poorly developed the official narrative is that guides the legislative efforts of the EU and its member states in the area of criminal justice. It is widely recognized, for instance, that the concept of European citizenship remains a vague notion in criminal justice. ${ }^{1}$ The proper administration of justice is another central element of cooperation in criminal matters, but only referred to in passing. ${ }^{2}$ The goals of this article are to identify the dominant narratives that define the nature and characteristics of European cooperation in criminal matters. Moreover, this article aims to identify the consequences that these narratives entail for the protection of fundamental rights in that cooperation and, subsequently, for the EU's legislative agenda for the coming years.

Such an effort requires, first of all, an analysis of the nature of that cooperation (section 2). It is submitted in this article that that nature has changed dramatically, even though that was not so obvious at the time that the principle of mutual recognition was introduced as the cornerstone for cooperation. Under the prevailing constitutional framework, a series of innovative cooperation instruments have been developed that supplement each other and, as will be explained below (section 2.2), have even come to serve as mutual alternatives. What these instruments have in common, is that they all do away with the traditional narrative of cooperation as an international law affair between sovereign legal orders. Rather, they approach cooperation as a transnational affair, for the benefit of swift and effective criminal law enforcement in order to contribute to the goals of a common Area of Freedom, Security and Justice.

How one approaches the nature of cooperation in criminal matters is a particularly relevant issue when it comes to the protection of fundamental rights. Under the international law narrative, fundamental rights are particularly relevant for the degree of trust in other sovereign legal orders; nothing less, but

1 See, in extenso, recently S. Coutts, Citizenship, crime and community in the European Union (Hart 2019).

2 As rightfully highlighted by A. Klip, European criminal law - An integrative approach (Intersentia 2016), p. 533-534, 541-543. 
certainly nothing more than that. Remarkably, the debates in the EU go along similar lines; their focus, too, is on the role of fundamental rights as an impediment to cooperation ${ }^{3}$ and on their role as a means to promote trust in the individual criminal justice systems of the EU Member States (section 4.1). Consequently, where law enforcement cooperation has become transnational, fundamental rights retain ${ }^{4}$ an almost exclusive national focus. ${ }^{5}$ In section 3 , I will identify a number of problems that consequently remain disregarded. The question is to which extent these problems present mere 'practical inconveniences', inherent to transnational cooperation, like in international criminal law, ${ }^{6}$ or whether they have become, in light of the new EU narrative, fundamental rights problems that require an answer by the EU and its Member States (section 3).

This article will then develop a new narrative, in light of the needs of a common rea of Freedom, Security and Justice, the interests of EU citizens, and the proper administration of justice (section 4.2). That narrative does not do away with the position of states as the main vehicle for the administration of criminal justice. ${ }^{7}$ It does however seek to explain that were such notions as 'territory', 'diplomacy' or 'borders' are removed from the equation (to the benefit of mutual coordination, direct consultations and dialogues, as well as joint investigations), that automatically reveals new types of discretion for the police, prosecutors and also courts, that have this far remained unidentified and under-regulated. The consequence of such a change in narrative is after all that criminal investigations from different legal orders become - and are deliberately intended to become - 'inextricably connected', in substance, time and territorial scope. What happens in criminal investigations in one legal order, will automatically have consequences for the legal position of individuals

3 ECJ 5 April 2016, joined cases C-404/15 en C-659/15 PPU (Aranyosi and Căldăraru), ECLI:EU:C:2016:198, and ECJ 25 July 2018, Case C-216/18 PPU (LM), ECLI:EU:C:2018:586.

4 'Retain', because that was already the case under international law cooperation instruments.

5 The ne bis in idem principle is of course the notable exception. The question is why it is the only right that has been given an explicit transnational scope this far.

6 The ECtHR has repeatedly accepted the complexities of international cooperation as a factor that mitigates the effects of fundamental rights, see in extenso A.A.H. van Hoek \& M.J.J.P. Luchtman, 'Transnational Cooperation in Criminal Matters and the Safeguarding of Human Rights', Utrecht Law Review 1(2) 2005, pp. 1-39.

7 A particularly urgent matter, of course, is the independence of the judiciary; see ECJ 25 July 2018, Case C-216/18 PPU (LM), ECLI:EU:C:2018:586, but also ECJ 27 May 2019, Case C-509/18 (PF), ECLI:EU:C:2019:457, Joined Cases C-508/18 and C-82/19 PPU (OG and PI), ECLI:EU: C:2019:456, and ECJ 9 October 2019, Case C-489/19 PPU, (NJ ((Parquet de Vienne)), ECLI: EU:C:2019:849. 
in another. That development does not necessarily go well with the concept of free movement of persons and the idea of transnational agency it entails.

Though official discourse remains silent on it, the changes in the nature of European cooperation in criminal matters therefore have far-reaching consequences. They move away from mutual recognition as the dominant concept for the governance of the Area of Freedom, Security and Justice ${ }^{8}$ and call for a model of deeper justice integration, based on a common European area, fostering the proper administration of criminal justice and transnational agency for individuals (which is related to, but not the same as European citizenship). In the final section of this article, I will outline what this could and should mean for the focus of the new multi-annual legislative agenda that is currently being developed. The goal is not to develop specific proposals, as it is the idea behind European cooperation in criminal matters itself - and, equally important, the open attitude it requires from all actors that together shape and define the European legal order - that merits attention first. It is possible, however, to roughly identify the main priority issues in light of the changed nature of European cooperation in criminal matters (section 5 ).

\section{Two Different Views on European Cooperation in Criminal Matters}

\subsection{International Cooperation in Criminal Matters}

European law and criminal law have long been regarded as two relatively separated areas of law. Even today, some trademarks in the EU system of competences still reflect the special position criminal justice has within the EU setting. ${ }^{9}$ But despite this, many of the innovations in transnational enforcement cooperation come precisely from the domain of criminal law. Cooperation on the basis of mutual recognition, for instance, was introduced as a radical alternative to harmonization, intended to adjust criminal justice to a Europe without borders and to replace instruments of mutual legal assistance (MLA). Another example is the future European Public Prosecutor's Office (EPPO), which will without doubt be a true laboratory for enforcement cooperation and integration, once operational.

8 S.K. Schmidt (ed.), Mutual Recognition as a New Mode of Governance (Routledge 2008).

9 So-called emergence break procedures exist, for instance, to protect the fundamental aspects of a Member State's criminal justice system (Arts. 82 (3) and 83 (3) TFEU). 
What precisely are the changes that this Europeanization of cooperation has brought? No doubt that these processes have really took flight with the introduction of the principle of mutual recognition and the first instrument that was built upon it, the Framework Decision on the European Arrest Warrant. ${ }^{10}$ Traditional extradition procedures are characterized by their dual character. This is because this form of cooperation is perceived as a form of international cooperation, which explains why these procedures do not only involve courts and prosecutors, but also the representatives of the state, usually the ministries of foreign affairs. ${ }^{11}$ Moreover, the characterization of extradition as a matter of and between sovereign states is reflected in the substance of extradition law, in which the principles of interstate comity and reciprocity are clearly reflected via, for instance, the requirement of double criminality.

The new regime for the surrender of persons within the European Union and many other instruments in its wake - does away with many of these characteristics. It intends to speed up the procedures and to reduce enforcement deficits by removing from it those elements that characterize extradition law as a matter between states. Cooperation under the principle of mutual recognition is presented as a form of cooperation between judicial authorities and operates under a rule of mutual recognition of judicial decisions. Arrest warrants from other EU states are to be recognized as such and to be executed swiftly and preferably automatically. ${ }^{12}$ The role of the executive has consequently been more or less eliminated from surrender procedures and the number of refusal grounds have been reduced. However, the final text of the framework decision did not go as far as the original Commission proposal. ${ }^{13}$ The requirement of double criminality was for instance not banned, but reduced, and the initial references to EU citizens - instead of national citizenship were not implemented in the text.

The new regime quickly led to pertinent questions. What would be its implications for the exception of nationality in extradition law, prohibiting the

10 Framework Decision 2002/584/JHA on the European arrest warrant and the surrender procedures between Member States, OJ [2002] L 19o/1.

$11 C f$. A. Eser, Lagodny O. \& C.L. Blakesley (eds.), The individual as subject of international cooperation in criminal matters (Nomos 2002); K. Ambos, European criminal law (CUP 2018), p. 419, 433 .

12 A.H.J. Swart, Een ware Europese rechtsruime: wederzijdse erkenning van strafrechtelijke beslissingen in de Europese Unie (Kluwer 2001), p. 16-17; J. Spencer, 'Mutual recognition and choice of forum', in M. Luchtman (ed.), Choice of forum in cooperation against EU financial crime - freedom, security and justice \& the protection of specific EU-interests (Boom/ Lemma 2013), p. 61 at p. 61; V. Mitsilegas, EU criminal law after Lisbon - Rights, trust and the transformation of justice in Europe (Hart 2016), p. 125-126. $\operatorname{com}(2001) 5^{22 .}$ 
extradition of a country's own nationals? And, in light of the reduction of the condition of double criminality, how to deal with extraterritorial claims of jurisdiction, particularly when they relate to acts that occurred on the territory of the executing state? The first real test for the new system was presented by the famous Darkanzanli case. Darkanzanli was taken into custody by German authorities on the basis of a Spanish Arrest Warrant in October 2004, after a previous extradition request - prior to the entry into force of the new regime was refused on the basis of his German nationality. ${ }^{14}$ Darkanzanli's surrender was requested - ordered - on account of his alleged role within the Al-Qaida terror network since 1997. Parts of the actions that were under investigations allegedly took place on German territory and where not criminal offences (yet) at the time of action under German law.

The case of a German national, under investigation for actions that took place on German soil and were not criminal offences yet, soon proved to be a very controversial affair. The case went up quickly to the German Federal Constitutional Court. ${ }^{15}$ In an elaborated judgment, that Court came to a very principled conclusion. It held that the revised Article 16 (2) and the principle of the rule of law of the German Constitution protects the 'prosecuted person's confidence in his or her own legal system (...), where the act on which the request for extradition is based has been committed in whole or in part on German territory (...). Charges of criminal acts with such a significant domestic connecting factor are, in principle, to be investigated in the domestic territory by German investigation authorities if those suspected of the criminal act are German citizens.' ${ }^{16}$ This, however, does not go for cases without such a connecting German factor or in cases of mixed character (both German and foreign elements to the case). ${ }^{17}$

Consequently, the Court annulled the German law implementing the Framework Decision on account of the fact that that law did not sufficiently use the possibilities, offered by the Framework decision, to take account of these specific interests. ${ }^{18}$ Though the Court thus averted an open conflict with the European Union and explicitly positioned the German legal order as 'open' to European cooperation in criminal matters, it also sent a warning signal,

\footnotetext{
14 Art. 16 of the German Constitution. Darkanzanli also possesed the Syrian nationality.

15 Bundesverfassungsgericht, 18 July 2005, 2 BvR 2236/04 (Darkanzanli), discussed by Ambos, supra note 11, p. 442-446.

16 Bundesverfassungsgericht, 18 July 2005, 2 BvR 2236/04, non-official English translation by the Court, para 84 .

17 Ibid., para 84-88.

18 It did so not only on the basis of Art. 16 of the Constitution, but also on the basis of Arts. 19 IV (the so-called Rechtsweggarantie) and 103 (legality principle) Constitution.
} 
quite in line with its well-known position. It held that '[i]n spite of the advanced state of integration, European Union law is still a partial legal system that is deliberately assigned to public international law. This means that a Framework Decision must be adopted unanimously by the Council, it requires incorporation into national law by the Member States, and incorporation is not enforceable before a court. The European Parliament, autonomous source of legitimisation of European law, is merely consulted during the lawmaking process (...), which, in the area of the "Third Pillar", meets the requirements of the principle of democracy because the Member States' legislative bodies retain the political power of drafting in the context of implementation, if necessary also by denying implementation [emphasis added].19

The message was clear. Former third pillar legislation cannot replace the nation-state - the Federal Republic of Germany - as the vehicle for the promotion of the rule of law, fundamental rights and democracy, nor is that position in contradiction to the new regime. To the contrary, in the Constitutional Court's view, 'the cooperation that is put into practice in the "Third Pillar" of the European Union in the shape of limited mutual recognition, which does not provide for a general harmonisation of the Member States' systems of criminal law, is a way of preserving national identity and statehood in a single European judicial area. ${ }^{20}$ Consequently also, the focus is on the protection of German nationals, not on EU-citizens on German soil or, vice versa, the interests of non-German nationals in cases of the exercise of extraterritorial jurisdiction by German authorities.

The Federal Constitutional Court has not significantly changed its position after the entry into force of the Lisbon Treaty. In its wording since, the Court keeps referring to surrender law as a form of international cooperation. Consequently, its terminology refers to extradition, requesting and requested states, not to surrender, issuing or executing states. ${ }^{21}$ Though the German legal order is open to European integration and recognizes that EU law may take precedence, this can never lead to a situation where German - legislative, judicial or executive - bodies can escape the constitutional order of the Constitution, as interpreted by that Court, particularly not in the area of criminal justice. The $\mathrm{EU}$ is referred to as a 'derived fundamental order. ${ }^{22}$

\footnotetext{
$19 \quad$ Ibid., para 81.

$20 \quad$ Ibid., para 76 .

21 See Bundesverfassungsgericht 30 June 2009, BvE 2/o8, Lissabon Urteil, and Bundesverfassungsgericht, 15 December 2015, 2 BvR 2735/14.

Lissabon Urteil, ibid., para. 231.
} 


\subsection{Transnational Cooperation in Criminal Matters}

The position of the German Constitutional Court probably will find recognition by many; the picture of the new framework for surrender as an advanced form of international cooperation is still the prevailing perspective among many lawmakers, courts and practitioners, all over the European Union. ${ }^{23}$ However, a number of developments - both at the legislative level and in the case law of the Court of Justice - have put this position under pressure. This, in turn, may have consequences for how one perceives the role of fundamental rights in the European legal order.

One of the many paradoxes in the Brexit debate is, for instance, that the internationalist view of cooperation is increasingly put under pressure in (continental) Europe, even by those who are skeptical of further justice integration. After all, whereas the UK-government seeks ways to stay part of a number of the EU's most important instruments for cooperation (including the EAWregime, Eurojust and EU-databases), yet without accepting the direct competences of - particularly - the Court of Justice and essential EU law building locks such as the free movement of persons, the much heard counter-argument on the continent is that one cannot have these swift and effective mechanisms without a set of common goals, rules and principles and a final arbiter for cases of unclarity.

Indeed, the EU may be called a forerunner in the development of new formal and informal instruments for cross-border enforcement cooperation. Such new forms of cooperation include, first of all, the said mutual recognition instruments, including the pre-Lisbon European Arrest Warrant and the postLisbon European Investigation Order. ${ }^{24}$ Under these instruments, European orders or warrants basically reduce the degree of discretion for executing authorities to a minimum degree, thereby de facto extending the operational reach of the issuing authorities far beyond their territorial borders. ${ }^{25}$

The mutual recognition instruments are certainly not the only instruments for cooperation. They are part of a number of options that are available for transnational crime control. Whereas the mutual recognition instruments can be regarded as the successors of international mutual legal assistance arrangements, other forms of cooperation entirely do away with those arrangements. Among these instruments are joint investigation teams ${ }^{26}$ and enforcement

23 Cf. Ambos, supra note 11, p. 438.

24 Directive 2014/41/EU regarding the European Investigation Order in criminal matters, $O J$ [2014] L 130/1.

25 Cf. V. Mitsilegas, supra note 12, p. 126.

26 Council Framework Decision 2002/465/JHA on joint investigation teams, OJ [2002] L $162 / 1$. 
networks. ${ }^{27}$ Joint teams are established for specific investigations, networks, on the other hand, have a permanent character. The added value of these structures lies in the sharing of information and the 'pooling' of powers by authorities from different states for common operational purposes. Within joint teams, authorities cooperate on a direct basis, sharing information and gathering evidence without the traditional time consuming MLA-structures. The materials that they gather can be shared within the team and be introduced as evidence in another jurisdiction. Formal or informal networks of enforcement authorities work on a similar, yet more structural basis. Through close coordination and cooperation within those networks, it is not always necessary to issue time-consuming, formal requests for mutual legal assistance or administrative assistance. The networks 'simply' divide the tasks at hand and then mutually share the results without much formalities.

In the third place, we notice new forms of supranational enforcement, under which EU authorities (bodies, agencies and institutions) with EU-wide mandates ${ }^{28}$ fulfil tasks and duties of investigating, prosecuting or sanctioning of substantive norms of EU law directly vis-à-vis private actors. The European Public Prosecutor's Office is the most prominent example of this (I will come back to this body below), ${ }^{29}$ but there are other examples in the area of administrative enforcement as well. ${ }^{30}$

Finally, proposals were recently launched for a framework for European Production and Preservation Orders, under which certain law enforcement officials in one state can issue Production or Preservation Orders directly to a service provider in another state, without the intervention of the authorities of the latter state. ${ }^{31}$ Only in second instance, where execution by the provider does not take place, may enforcement orders be issued, that consequently need to be enforced through a mutual recognition regime.

27 The European Competition Network is a good example. Other networks with direct relevance for criminal justice are to be found in environmental law (IMPEL), food fraud (Food Fraud Network/FFN), consumer protection law (CPC network).

28 Or rather, with a mandate for the joint (European parts of the) territories of the participating states.

29 Council Regulation (EU) 2017/1939 implementing enhanced cooperation on the establishment of the European Public Prosecutor's Office ('the EPPO'), OJ [2017] L 283/1.

30 M. Luchtman \& J.Vervaele (eds.), Investigatory powers and procedural safeguards: Improving OLAF's legislative framework through a comparison with other EU law enforcement authorities (ECN/ESMA/ECB) (Utrecht University 2017), p. 248; M. Scholten \& M. Luchtman (eds.), Law Enforcement by EU Authorities - Implications for Political and Judicial Accountability (Edward Elgar 2017).

31 Proposal for a Regulation on European Production and Preservation Orders for electronic evidence in criminal matters, $\operatorname{COM} / 2018 / 225$. 
All of these developments urge the need to adjust the empirical lens trough which criminal cooperation is analyzed. What these instruments have in common, is that they aim to overcome, one way or another, the territorial boundaries of the nation-state with respect to enforcement jurisdiction. They aim to do away with the traditional instruments for international mutual legal assistance in criminal matters to speed up the fight against crime and to reduce transnational enforcement deficits. The new instruments have gotten rid - though not always fully successfully - of the formal interventions of state ministries (as representatives of the nation state) and in many cases also with the many conditions for and refusal grounds within mutual legal assistance schemes. ${ }^{32}$

Whereas the new forms of cooperation on, the one hand, thus extend the long arm of criminal justice systems far beyond territorial borders, they also urge those systems to adopt an open attitude. They require Member States to operate under a regime of automatic cooperation as executing state or even to allow foreign or European authorities to become active on their territory (although the latter does not imply that the use of physical coercion is also 'outsourced'). Consequently, the political oversight of the state where investigatory measures are executed, is also reduced or even eliminated.

It is no coincidence that these forms of cooperation have come to full development and are used particularly within the setting of the European Union. The systematic reduction or elimination of the building blocks for international law cooperation from the cooperation instruments cannot lead to a legal vacuum, as this would affect both the effectiveness of the instruments as well as the legal protection they offer. That is why the international law narrative is in the process of being replaced by a European narrative, based on Article 3 (2) TEU; the EU must offer its citizens an area of freedom, security and justice without internal frontiers, in which the free movement of persons is ensured in conjunction with appropriate measures with respect to the prevention and combating of crime. The EU has acquired the functional powers to shape this area through competences in the area of cooperation, approximation of laws and through European institution building (Eurojust, the European Public Prosecutor's office). And indeed, the EU actively uses these competences, inter alia for a number of instruments harmonizing defence rights, which also apply where no specific transnational element is present. ${ }^{33}$ The relevance of the EU Charter of Fundamental Rights, as well as of other principles of EU law for the

32 Joint investigation teams, incidentally, are established via MLA requests.

33 See the Resolution of the Council on a Roadmap for strengthening procedural rights of suspected or accused persons in criminal proceedings, OJ [2009] C 295/1, discussed, inter alia, by Klip 2016, supra note 2, p. 260 et seq. and S. Allegrezza \& V. Covolo (eds.), Effective defence rights in criminal proceedings (Wolters Kluwer 2018). 
administration of criminal justice have consequently grown significantly. Said instruments have provided the EU and its institutions with a significant influence on national criminal justice systems. Together with the efforts that are put in the development of direct contacts and enforcement networks, they aim to boost mutual trust in each other's legal systems. Of course, the recent case law with respect to who are 'issuing judicial authorities' as meant in the Framework decision on the European Arrest warrant, ${ }^{34}$ must also be seen in this light. ${ }^{35}$

All of these factors - the new forms for cooperation, their characteristics, as well as the accompanying narrative - make it impossible to keep referring to cooperation in criminal matters as a (predominantly) international law affair. Quite to the contrary, as all of their innovations are sought in removing territorial borders as an impediment to extraterritorial enforcement jurisdiction and as all approaches and instruments of international law are taken out of the narrative, transnational cooperation appears to be a more accurate qualification of the processes that take place. 'Transnational' means that the actors of criminal justice 'pierce the veil' of the nation state and seek cooperation with each other directly, without the intervention of their state representatives, to realize a common European goal, defined in abstracto by Art. 3(2) TEU, ${ }^{36}$ and to be filled in further by the EU polity of states and citizens.

A system like this builds upon trust, a common narrative, dialogue and a certain division of labor. Although the Court has never put it this way explicitly, its case law presupposes that the tasks and mandates of national authorities in the criminal justice area have acquired a European dimension, related to the further development of the AFSJ. ${ }^{37}$ Specifically for courts, this dimension not only includes a close working relationship with the Court of Justice itself, but also a horizontal relationship with judicial authorities from other Member States. In $L M$, dealing with the surrender of persons to Poland despite the reforms of the Polish judiciary and their implications for judicial independence, the ECJ explicitly refers to this dialogue between the executing

34 Similar questions have meanwhile been asked for the operation of the European Investigation Order, see $\mathrm{C}-584 / 19$ (Staatsanwaltschaft Wien).

35 ECJ 27 May 2019, Case C-509/18 (PF), ECLI:EU:C:2019:457, Joined Cases C-508/18 and C-82/19 PPU (OG and PI), ECLI:EU:C:2019:456, and ECJ 9 October 2019, Case C-489/19 PPU, (NJ ((Parquet de Vienne)), ECLI:EU:C:2019:849.

36 This definition differs from N. Boister, An introduction to transnational criminal law (ouP 2012); N. Boister, 'Further reflections on the concept of transnational criminal law', 6 Transnational Legal Theory (2015), p. 9-30; S. Gless, 'Bird's-eye view and worm's-eye view: Towards a defendant-based approach in transnational criminal law,' 6 Transnational Legal Theory (2015), p. 117-140. ECJ 5 April 2016, joined cases C-404/15 en C-659/15 PPU, Aranyosi en Căldăraru, para 79. 
and Polish judicial authorities as an instrument to deal with this systemic crisis. The ECJ held that, within the framework of this dialogue, 'the [issuing authorities] may, where appropriate, provide the executing judicial authority with any objective material on any changes concerning the conditions for protecting the guarantee of judicial independence in the issuing Member State, material which may rule out the existence of that risk for the individual concerned. 38

Yet also in other instruments - outside the framework of vertical and horizontal judicial dialogues - one notices the emphasis that is put on direct consultation and coordination between the authorities involved. ${ }^{39}$ Consequently, it may be - or perhaps better: it has become - somewhat misleading to refer to the principle of mutual recognition as the dominant model of governance of the Area of Freedom, Security and Justice. Rather, the promotion of dialogue, coordination and consultation facilitates and stimulates the creation of networks, joint teams and EU enforcement authorities that facilitate and coordinate cross-border investigations. To that extent, the many different instruments for EU cooperation in criminal matters have become mutual alternatives and re-enforce each other. They may even be applied cumulatively in one and the same criminal case. The ultimate illustration of the importance of these processes is, of course, Eurojust. ${ }^{40}$ Though it does not have, like the Court of Justice, binding powers to clear open issues or resolve conflicts between authorities, it plays a vital role in the facilitation of transnational cooperation.

In light of all this, it is time to recognize - instead of playing down its importance - that the legal order of the EU has played a very important role in these processes and innovations. Also in the area of criminal justice, the EU is not a derivate or a derived legal order. In light of the narrative, instruments, rules, procedures and institutions it has developed, the EU must be recognized as a legal order of its own. Its added value is, as has been noted before, ${ }^{41}$ threefold:

38 ECJ 25 July 2018, Case C-216/18 PPU, LM, ECLI:EU:C:2018:586, para 77.

39 See for instance the many references to such consultations in the framework for the European Investigation Order, supra note 24.

40 Per 12 December 2019, the Eurojust Council Decision 2002/187/JHA will be replaced by Regulation 2018/1727 on the European Union Agency for Criminal Justice Cooperation (Eurojust), OJ [2018] L 295/138.

41 Most notably by M. Poiares Maduro, 'Three claims of constitutional pluralism', in M. Avbelj \& J. Komárek (eds.), Constitutional pluralism in the European Union and beyond (Hart 2012), p. 67-84, and, in reaction, J. Komárek, 'European constitutionalism and the European Arrest Warrant: in search of the limits of "contrapunctual principles"', 44 CMLR (2007), p. 9-40. On the EU as a sovereign also N. Walker, 'Late sovereignty in the European Union,' in N. Walker (ed.), Sovereignty in transition (Hart 2003), p. 3-32. 
1. The EU offers its member states the opportunity to regain control over crime related problems which have become too big for individual states. Those problems require swift and effective cooperation, tackling both concerns of crime control as well as of due process.

2. The EU possesses the instruments to open up, if necessary, national legal systems, also in the area of criminal justice. Those who strive to regain control over crime, can not only promote their own interests and perspectives. They need to be open to the interests of other legal orders. Common goals, procedures, institutions and narratives are offered by the EU. They are centered on crime control, as well as due process, as is apparent from Articles 2 and 3 TEU.

3. A membership to the EU and the constitutional principles on which it is based also imposes what has been called 'external constitutional discipline' on the Member States, and one which is particularly important in criminal matters these days. The promotion of a dialogue between the Polish judiciary and its European colleagues in surrender law in $L M$ is an illustration of this. ${ }^{42}$ Judicial independence has been put forward as an essential component of the EAW system. ${ }^{43}$ Refraining from executing a Polish EAW is allegedly a more efficient measure to restore judicial independence than any political declaration, although we must wait and see what will happen in the years to come.

It is time, therefore, to recognize that the EU and its Member States have together turned in new roads, in which criminal justice systems are no longer fully autonomous systems, but are interdependent. Though the nation state will remain, under the existing Treaties, the main vehicle for the administration of criminal justice, cooperation in criminal matters has become a phenomenon in which all three traditional state branches - particularly the executive and judiciary - seek and are encouraged to seek direct contact with their respective EU-partners. To that extent, the qualification of the legal order of the EU and its Member States as a composite order is appropriate. It recognizes that police and prosecutors set common priorities in mutual, transnational consultations. It acknowledges that new routes for the development of case law in criminal matters - via Luxembourg - have an impact on the very foundations of any criminal justice system. ${ }^{44}$ Yet it also begs questions,

\footnotetext{
$42 \quad$ Supra note 38.

43 Recently reiterated by ECJ 27 May 2019, Case C-509/18 (PF), ECLI:EU:C:2019:457, and Joined Cases C-508/18 and C-82/19 PPU (OG and PI), ECLI:EU:C:2019:456.

44 Mitsilegas, supra note 25, p. 176-180, 183-184.
} 
particularly in the area of criminal justice, on the impact of all this on fundamental rights and their adaptation to this composite setting.

\section{Transnational Cooperation, Sovereignty and Fundamental Rights}

\subsection{Introduction}

Of course, though transnational European cooperation offers advantages and innovations, it also conflicts with other interests. The picture that emerges from the preceding section is one of Europe's criminal justice area as an area in which the administration of criminal justice is perceived as a joint task of the relevant national (and European) authorities. ${ }^{45}$ Clearly, that image does not go well with national perspectives on sovereignty and on international cooperation. And indeed, the legal frameworks for the new instruments still take account of the protection of national citizens, as was the case in Darkanzanli; of the desire to maintain the monopoly on the use of force in national hands; and of the possibility not to cooperate where one's own ordre public is in play or when such cooperation may hamper ongoing national criminal investigations. All of these interests are related to state sovereignty. ${ }^{46}$ Other EU-initiatives even proved too sensitive for enactment into law. Legislative proposals for transfers of proceedings, ${ }^{47}$ choices of forum ${ }^{48}$ or the admissibility of evidence ${ }^{49}$ were never adopted or even initiated.

Consequently, the picture that emerges is ambiguous. Transnational cooperation is promoted, but often not qualified as such. Swift cooperation is perceived as good and prevents 'criminals from escaping justice', ${ }^{50}$ yet not at the expense of a number of sovereign interests. Full mutual recognition instruments therefore do not exist, nor can we imagine foreign or European authorities using coercive force on national territory in full autonomy. Many existing instruments read as an attempt to reconcile both visions on cooperation. That is why, as said, the effects of the condition of double criminality have been reduced in the Framework Decision on the European Arrest Warrant only for the

\footnotetext{
$45 C f$. L. Besselink, A composite European Constitution (Europa Law Publishing 2007).

46 Cf. Swart, supra note 12, p. 17-19, 26-28.

47 See the Initiative for a Council Framework Decision on transfer of proceedings in criminal matters, OJ [2009] C 219/7.

48 Most recently by Ligeti \& Robinson (eds.), Preventing and resolving conflicts of jurisdiction in EU criminal law (OUP 2018).

49 Green paper on obtaining evidence in criminal matters from one Member State to another and securing its admissibility, $\operatorname{COM}(2009) 624$.

Presidency Conclusions of the European Council in Tampere, October 1999, sub 5 .
} 
so-called 32 list offences. It is also why the exception of nationality in cases of the surrender of persons has not been abolished, although the Court of Justice has meanwhile made clear that these conditions and refusal grounds are to be interpreted in light of the principle of mutual recognition and has given them a 'European twist.'51

Another example of these tensions is offered by the legal framework for the European Public Prosecutor's Office. The EPPO is a European body that is responsible for the investigation and prosecution (before national courts) of crimes related to, for the time being, fraud against the EU's financial interests. ${ }^{52}$ Yet despite its broad territorial mandate - covering the joint territories of the 22 participating states -, it does not operate on the basis of a common European code. The legal design of the EPPO reflects the will of the EU legislator to be as decentralized as possible. Though the EPPO-regulation does lay out the main features of its organizational setup, it refers back to national law in many instances, including the precise definition of the offences and the sanctions applicable. There is no uniform set of investigative powers, nor a complete set of defence rights at EU level. Legal protection has moreover predominantly been put in the hands of national courts, because the EPPO's cases will ultimately be brought before and tried by national courts. ${ }^{53}$

Already during the lengthy negotiations, further decentralizations were implemented in its design. The EPPO has now lost the proposed exclusive jurisdiction over EU financial fraud and its organizational structures may be called 'challenging. ${ }^{44}$ Yet even under those circumstances, its coming into being still proved a bridge too far for a number of EU States. The foregoing means that the EPPO will have a broad territorial mandate - hence doing away with most of the time consuming mutual legal assistance agreements ${ }^{55}$-, but on the basis of a decentralized design and a limited harmonization of the underlying offences, investigatory powers, safeguards, as well as remedies. That means that, depending on where it operates, its procedural toolkit will be different.

$5^{1} \quad$ ECJ, 29 June 2017, Case C-579/15, Poptawski, para 21.

52 Supra note 29.

53 Commission proposal, (2013) 534, p. 7, discussed by A. Meij, 'Some Explorations into the EPPo's Administrative Structure and Judicial Review', in L.H. Erkelens et al. (eds.), The European Public Prosecutor's Office: An Extended Arm or a Two-Headed Dragon? (Asser Press 2014) and Herrnfeld, 'Choice of forum and case allocation in the EPPO regulation', in Ligeti \& Marletta, supra note 48, p. 305.

54 See M. Luchtman and J. Vervaele, 'European Agencies for Criminal Justice and Shared Enforcement (Eurojust and the European Public Prosecutor's Office)', 10 Utrecht Law Review (2014), p. 132-150.

55 See however art. 33 EPPO Regulation, dealing with European Arrest Warrants. 
These hybrid structures may, first of all, cause problems for the involved authorities, who continuously need to be aware of the fact that materials which have been gathered in one jurisdiction may be presented as evidence in another, under a different set of rules. In the second place, the degree of decentralization and the differentiation at the national level have consequences for the protection of fundamental rights of accused persons (and others involved in criminal justice) in transnational situations.

It is well documented in international criminal law what problems these individuals face. ${ }^{56}$ In the following sections, I will discuss those problems, with adaptations to the setting of the EU. After that, I will make an effort on how to normatively assess them. The following subsequently deals with problems relating to the foreseeability of the applicable laws, with the law's incapability to prevent a fragmentation of defence rights, procedural safeguards, and remedies, and with the adverse consequences of multiplications of procedures and excessive sanctioning.

\subsection{The Foreseeability of the Applicable Law}

The state of the art presents problems for individuals with respect to the foreseeability and accessibility of the law defining the offences, sanctions, procedures and defence rights and investigatory powers. ${ }^{57}$ It was noticed in the above that the EU instruments have widened the operational scope of national and EU authorities. Extraterritorial claims of prescriptive (legislative) jurisdiction further increase the potential for conflicts, ${ }^{58}$ certainly now that EU law encourages its citizens to move freely across Europe, thus triggering the applicability of a multitude of national laws. It is not uncommon, for instance, for states to establish jurisdiction not only on the basis of a territorial link, but also on the basis of nationality (of the offender or of the victim).

In situations like these, a fight in France between a Dutchman and a German, resulting in serious bodily harm for the German victim, has legal implications for all three legal orders. It may trigger a prosecution in the Netherlands, upon return to that country, but it may also lead to prosecutions in Germany and/or France. In the latter situation, both countries may issue European

56 See, particularly Eser et al., supra note 11; A. Orie, 'De verdachte tussen wal en schip òf de systeem-breuk in de kleine rechtshulp,' in E. André de la Porte (ed.), Bij deze stand van zaken (Gouda Quint 1983); A.H. Klip, 'The Decrease of Protection under Human Rights Treaties in International Criminal Law', 68 International Review of Penal Law (1997), p. 291-310.

57 See Luchtman/Vervaele 2014, supra note 54.

$5^{8}$ On the concepts of jurisdiction to enforce and to prescribe, see the European Committee on Crime Problems, Extraterritorial criminal jurisdiction (Council of Europe 1990). 
Arrest Warrants to the Dutch authorities, for the purpose of prosecution, according to German or French law. Relevant questions then are to which extent the offender must have been able to know for which (Dutch, German and/or French) offences he is liable and which sanctions can eventually be imposed on him, given that the applicable sanctions vary considerably across the relevant legal orders. Similar issues arise with respect to the procedural principle of legality; ${ }^{59}$ to which extent - and at which stage - do individuals need to be able to know where they will be tried, so that they can determine the scope of their procedural rights and effectuate their defence strategies? The aforementioned instruments for transnational cooperation do not contain guidance on this.

Where the mandates of the authorities overlap, there automatically emerges a discretionary space, which has significant impact on the individual who is availing himself of his free movement rights or who is confronted with the movement of others. Of course, national authorities are ultimately bound by their own national laws. The point is, however, that they have a decisive influence on whether they wish to be bound by that law. Through mutual coordination these authorities are able to exert considerable influence on the course of criminal proceedings. For example, there have been many examples of cases where suspects were transferred from one jurisdiction to another on account of the fact that codefendants were also in the issuing state. Indeed, the administration of justice may require a combined procedure against all defendants. Yet what remains unsaid in those cases is that these codefendants were also brought there by EAW's. Should one close the eyes for this kind of influence on the administration of justice by the cooperating authorities, or not? That remains an open question to this date in EU law.

This problem becomes even more pressing where it is one authority which is given the discretion to determine the applicable substantive or procedural law. ${ }^{60}$ The EPPO has been put in the unique situation that its territorial competence covers the joint territories of 22 states. Even though the EPPO regulation has introduced an obligatory mechanism for forum choices in criminal law - a small revolution in itself -, its wordings still offers EPPO officials a considerable degree of discretion in determining the relevant jurisdiction(s) for its activities, whereas the substantive and procedural frameworks, still largely defined by national law, differ significantly. The same offence may for instance

$59 \quad$ Nullum judicium sine lege; see Arts. 6 ECHR and 47/48 CFR.

6o $\quad C f$. Herrnfeld, supra note 53, p. 312 et seq. 
give rise to four years of prison sentence in one state and ten in another. ${ }^{61} \mathrm{How}$, then, will the EPPO determine the appropriate forum? What possibilities for review are there? Are national courts apt to their new task in this regard? From a perspective of equality of arms, this situation - where one party to the proceedings basically is able to unilaterally determine the applicable legal framework - does not seem to be a particularly fortunate choice. It remains to be seen what role national courts will assume in this situation and what role the Court of Justice will play. ${ }^{62}$

\subsection{Rights, Safeguards and Remedies in Composite Procedures}

Overlapping competences under diverging legal systems not only raise issues in terms of the applicable law, the necessity for cooperation it stimulates - and aims to stimulate - also leads to a fragmentation of defence rights and procedural safeguards. This problem is also well-documented in international criminal law. ${ }^{63}$

Defence rights such as the privilege against self-incrimination are at stake, for instance, where administrative proceedings in one jurisdiction run in parallel to criminal procedures in another. The point in those cases is that EU law will stimulate or even oblige the relevant authorities to cooperate, also transnationally, whereas the Strasbourg court - in national cases - has held that such sharing of information is likely to affect the said privilege. ${ }^{64}$ It implies, after all, that one is obliged to provide information under administrative law, yet simultaneously is entitled to the privilege in criminal matters. How does this work out in cases where administrative investigations take place in one state and criminal investigations in another, as is the case in many ongoing transnational fraud investigations? Assuming such procedures are sufficiently interlinked, ${ }^{65}$ it may be derived from the Strasbourg case law that there must then be either a ban on the use of compulsion in the non-punitive procedures or a ban on the use of the obtained information for punitive purposes. Yet the full implementation of this safeguard would require legislative interventions at EU level and the willingness of national legal orders to implement it. As long

61 Situations like these remind of a transnational application ECtHR 22 January 2013, Camilleri v. Malta, appl. no. 42931/10, certainly when minimum penalties are concerned.

62 See Art. 42 and Recitals 87 and 88 of the EP PO Regulation, discussed in Luchtman (2018), supra note 53 .

63 Orie, supra note 56 ; M. Luchtman, European cooperation between financial supervisory authorities, tax authorities and judicial authorities (Intersentia 2008), p. 162 et seq.

64 Cf. ECtHR 21 April 2009, Marttinen v. Finland, appl. no. 19235/o3; ECtHR 5 April 2012, Chambaz v. Switzerland, appl.no. 11663/04.

65 '[S]uffisamment liées'; ECtHR 5 April 2012, Chambaz v. Switzerland, para 43. 
as the national administrative investigations are perceived as precisely that national proceedings -, these interventions are not likely to take place. The recent Directive 2016/343 does not explicitly tackle this situation in the national setting, ${ }^{66}$ let alone the transnational setting. Consequently, it remains to be seen if, should the situation arise, the European Court of Justice is willing to apply the Strasbourg case law to transnational cases on the basis of Arts. 47 and 48 of the Charter, and if so, to what results that would lead.

There are much more indications that rights, safeguards and the review of transnational cooperation remain fragmented along national lines, in the absence of a European narrative and corresponding legislation. The issue is also pertinent with respect to the admissibility of 'foreign' or 'EU' evidence in criminal proceedings. The question may then be, for instance, to which extent materials that have been gathered under different or 'lower' procedural standards are admissible as evidence, or how courts should respond to violations of safeguards or defence rights, committed by foreign or EU agents. The latter question usually involves a two step-approach, 1) the determination of a violation of law or condition for fair proceedings and 2) the determination of the adequate reaction to it. Yet in many legal orders, national courts do not apply such tests. In cases of alleged irregularities, they either accept foreign materials lawful or unlawful - only as starting information, thus requiring the necessary evidence to be collected again in accordance with national standards, or they accept the materials and refuse to hear the complaints, indicating that violations of, particularly, the right to privacy must be addressed in the state where the materials were collected. There is, according to this position, no need to hold foreign criminal justice actors to account, as those actors are not the agents of the forum state and the promotion of legal accountability is consequently useless.

The question is to what extent that position reflects the innovations that are brought by the new forms of cooperation. It obfuscates the role of the national authorities in the process of 'transnational coordination' and the many decisions that are taken by the cooperating authorities during that process, nor does it guarantee an effective remedy elsewhere. ${ }^{67}$ Yet where law enforcement is presented as a joint effort of the cooperating authorities, by removing the

66 Directive 2016/343 on the strengthening of certain aspects of the presumption of innocence and of the right to be present at the trial in criminal proceedings, OJ [2016] EU L $65 / 1$.

$67 \quad C f$. F. Meyer, ,Verbundstrafverfolgung in der EU', in F. Herzog (et al.), Rechtsstaatlicher Strafprozess und Bürgerrechte: Gedächtnisschrift für Edda Weßlau' (Duncker \& Humblot 2018), pp. 193-215; M. Shapiro, Implementation, discretion and rules', in: J. Vervaele (ed.), Compliance and enforcement of European Community law (Kluwer 1999), p. 27-34. 
national barriers from the scheme, does that not imply that these procedures become - in the words of 'Strasbourg' - sufficiently interlinked?68 If so, shouldn't this have consequences for the organization of the judicial (and political) oversight? At this stage, at any rate, there is no European framework for the organization of the two step procedure that was mentioned, whereas national courts only tend to focus on the role of 'their own' authorities. In transnational cases, all sorts of questions arise as to the applicability of the Charter, the scope of the rights in it and the allocation of responsibilities among states and state actors for interferences with Charter rights and safeguards. In the large majority of cases, again, EU legislation will be needed for guidance and national laws will be required to open up to these $\mathrm{EU}$ influences.

\subsection{Multiplication of Procedures and Preventing Excessive Sanctioning}

Two brief points need to be made on the third category of problems, which has already attracted much attention in academic writing. ${ }^{69}$ Even when the combined applicability of multiple national laws is perfectly foreseeable, multiple proceedings remain a reality for individuals. They imply the burden of having to face trial in multiple states, and of facing multiple sanctions. ${ }^{70}$ This far, the problem has been approached predominantly as an issue under the ne bis in idem principle (Art. 50 CFR) and, moreover, only for transnational ne bis in idem issues within criminal law sensu stricto. The burdens for individuals are, of course, much bigger. I will merely mention here the references that have already been made to the need for a coordinated criminal defence, ${ }^{71}$ and to the fact that ne bis in idem does not prevent the many situations of concursus, ${ }^{72}$ where cumulations of criminal procedures and sanctions - for different, yet

68 Supra note 65.

69 See, among many others, M. Mansdörfer, Das Prinzip ne bis in idem im europäischen Strafrecht (Duncker \& Humblot 2004); M. Petr, 'The ne bis in idem principle in competition law', 7 ECLR (2008), pp. 392-400; B. van Bockel, The 'ne bis in idem' principle in EU law (Kluwer 2010).

70 U. Sieber, 'Die Zukunft des Europäischen Strafrechts - Ein neuer Ansatz zu den Zielen und Modellen des europäischen Strafrechtssystems', 121 Zeitschrift fur die Gesamte Strafrechtswissenschaft (2009), pp. 1-67.

71 Cf. B. Schünemann (ed.), Ein Gesamtkonzept fur die europaische Strafrechtspflege (Heymanns 2006); European Criminal Policy Initiative, Manifesto on European Criminal Procedure Law (2013); Ambos, supra note 11, p. 24, 449-450.

72 Though the case was dealt with under the heading of the ne bis in idem principle, ECJ 3 April 2019, Case C-617/17 (Powszechny Zakład Ubezpieczeń na Życie), ECLI:EU:C:2019:283, basically deals with a situation of concursus in the application of national and EU competition law. The approach chosen by the Court is completely in line with its approach of the ne bis in idem principle in competition law. 
related offences - may lead to a punitive overreaction, that is only partially tackled by EU legislation. ${ }^{73}$

It must be noted, in the second place, that the ne bis in idem principle is one of the few guarantees which is implemented in a solid, transnational legal framework. Precisely because of the Schengen rules and their subsequent incorporation in EU law, the Court of Justice was able to develop its far reaching case law, promoting justice integration. This is illustrated by comparing the Schengen case law with the situation in competition law. Article 54 CISA ensures 'that a person whose trial has been finally disposed of is not prosecuted in several Contracting States for the same acts on account of his having exercised his right to freedom of movement, the aim being to ensure legal certainty - in the absence of harmonisation or approximation of the criminal laws of the Member States - through respect for decisions of public bodies which have become final. ${ }^{74}$ The situation is apparently different in competition law, where that same Court held that: '[a]s regards observance of the principle ne bis in idem, the application of that principle is subject to the threefold condition of identity of the facts, unity of offender and unity of the legal interest protected. Under that principle, therefore, the same person cannot be sanctioned more than once for a single unlawful course of conduct designed to protect the same legal asset. ${ }^{, 75}$ The respective competition laws of the EU, third states and the national laws of EU Member States do not protect the same legal interests, but only those of their specific legal order. That means that, though inconvenient for the (legal) persons involved, there is no issue of legal certainty, because the undertakings are able to determine their rights and obligations vis-à-vis the respective applicable laws. Bluntly said, the certainty that is provided is that it is clear that the safeguard of ne bis in idem does not cover the interactions between the different legal orders involved. ${ }^{76}$

73 Framework Decision 2008/675/JHA on taking account of convictions in the Member States of the European Union in the course of new criminal proceedings, OJ [2008] L $220 / 32$.

74 ECJ 29 June 2016, Case C-486/14, Kossowski, para. 44.

75 ECJ 7 January 2004, Aalborg Portland et al./Commission, Joined cases C-204/oo P, C-205/oo P, C-211/oo P, C-213/oo P, C-217/oo P and C-219/oo P, para 328; confirmed in ECJ 14 February 2012, Case C-17/10, Toshiba, para 97.

76 Of course, the Court did stipulate, already in ECJ 13 February 1969, Case 14/68, Walt Wilhelm, ECLI:EU:C:1969:4, para 11, that the principle of proportionality must be taken into account, also in cases of consecutive prosecutions/punishments for infringements of EU and national competition law. A similar approach was recently taken in cases of concursus, see ECJ 3 April 2019, Case C-617/17 (Powszechny Zaktad Ubezpieczeń na Życie), ECLI:EU:C:2019:283, para 38. 
The two divergent approaches to ne bis in idem are, in my view, indicative for the importance of EU legislation to overcome the problems that are addressed here. The fact that only Articles 50 and Art. 45 CFR have an explicit EU-wide applicability does not mean that other rights cannot have such a scope. However, the starting point of the Court seems to be that as long as EU law does not bridge the territorial and functional borders of the legal orders of the Member States, those orders are not likely to be held responsible for the actions that took place in another. Consequently, the $\mathrm{ECJ}$ is also unlikely to intervene. In the absence of secondary EU law, the Charter may not be in play, or - where it is applicable - the transnational scope of its fundamental rights - as well as its limitations - may remain unclear.

Two Visions on Fundamental Rights in a Composite Legal Order

\subsection{The Model of Equivalence}

It is a daunting task to reconcile considerations of crime control and due process in a framework for transnational cooperation. The current models for cooperation address fundamental rights mainly in two ways, i.e. as refusal grounds for cooperation, or in legislative and other efforts to boost mutual trust in the legal orders of the individual EU Member States. ${ }^{77}$ The foregoing section begs the question to which extent the European legal order should also take account of the concerns that were raised there. It is clear that those issues are currently not addressed. Yet for a composite legal order, in order to be able to refer to itself as a constitutional legal order, it must be able to embed the mechanisms for transnational cooperation in a constitutional framework that pays due attention to fundamental rights. Does the existing approach suffice for that?

The dominant vision connecting criminal law cooperation to fundamental rights in the EU's Area of Freedom, Security and Justice has been put forward by the Court of Justice in its Advice 2/13. The Court there presents what may be called a model of equivalence. It held that 'the founding treaties of the EU, unlike ordinary international treaties, established a new legal order, possessing its own institutions, for the benefit of which the Member States thereof have limited their sovereign rights, in ever wider fields, and the subjects of which

$77 C f$. the Commission Communication on 'A new EU Framework to strengthen the Rule of Law', $\operatorname{com}(2014) 158$. 
comprise not only those States but also their nationals. ${ }^{78}$ It went on to note that the EU's legal structure 'is based on the fundamental premiss that each Member State shares with all the other Member States, and recognises that they share with it, a set of common values on which the EU is founded, as stated in Article 2 TEU. That premiss implies and justifies the existence of mutual trust between the Member States that those values will be recognised and, therefore, that the law of the EU that implements them will be respected. ${ }^{79}$

Consequently, ' $[t]$ he principle of mutual trust between the Member States is of fundamental importance in EU law, given that it allows an area without internal borders to be created and maintained. That principle requires, particularly with regard to the area of freedom, security and justice, each of those States, save in exceptional circumstances, to consider all the other Member States to be complying with EU law and particularly with the fundamental rights recognised by EU law. Thus, when implementing EU law, the Member States may, under EU law, be required to presume that fundamental rights have been observed by the other Member States, so that not only may they not demand a higher level of national protection of fundamental rights from another Member State than that provided by EU law, but, save in exceptional cases, they may not check whether that other Member State has actually, in a specific case, observed the fundamental rights guaranteed by the EU. ${ }^{80}$ The Court thus provided for the foundations for legislation implementing two legal rules: a rule of recognition of equivalence and a rule of non-inquiry. ${ }^{81}$ Its considerations lay the groundwork for dealing with divergent systems and for organizing judicial control. As such, the Court's reasoning is not necessarily limited to instruments of mutual recognition. Its logic also applies to the other forms of cooperation mentioned in 2.2 .

The narrative of equivalence also sheds light on the relationships between the EU's approximation agenda and the instruments implementing the principle of mutual recognition. What the so-called Roadmap directives aim to achieve is, ${ }^{82}$ first and foremost, the promotion of mutual trust, via the introduction of common standards. Their importance is not so much found in their content (which does not always go beyond what we already know from

78 ECJ, Opinion of 18 December 2014 on the accession of theEUto the European Convention on Human Rights, para 157.

79 Ibid., para 168.

8 Ibid., para 192.

81 M. Luchtman, A.M. Karagianni \& K.H.P. Bovend'Eerdt, 'EU administrative investigations and the use of their results as evidence in national punitive proceedings', in: Fabio Giuffrida and Katalin Ligeti (eds.), Admissibility of oLAF Final Reports as Evidence in Criminal Proceedings, Luxembourg 2019. 
'Strasbourg'), but in the way in which they open-up national criminal justice systems to the instruments of EU law, including direct effect, consistent interpretation, autonomous interpretation, the applicability of the Charter and, last but not least, the competences of the Court of Justice and Commission.

It is not without reason that these developments have been referred to as a potential paradigm change in criminal justice, ${ }^{83}$ capable of shifting the balance from the ECtHR to the ECJ as the lead European court in matters of criminal justice. ${ }^{84}$ These developments illustrate that transnational cooperation and strengthening mutual trust are part and parcel of the same overarching strategy and one of the main reasons why European cooperation is markedly different from international cooperation.

\subsection{Towards a Model of Deeper Justice Integration?}

\section{2 .1 \\ Transnational Procedures: interlinked in time, Substance and Space}

The narrative of equivalence builds upon mutual recognition as the lead principle for the governance of the AFSJ. ${ }^{85}$ The emphasis is on the strengthening of the quality of the individual legal orders of the Member States, thus emphasizing the 'state model' in cooperation, but under a different narrative than in international criminal law.

That narrative is silent, however, on the aforementioned issues of the foreseeability of the applicable law, the fragmentation of rights, safeguards and remedies in composite procedures and of the multiplication of procedures and excessive sanctioning. These issues cannot be linked to specific legal orders; they occur at their mutual interfaces and relate to the discretionary margins that the cooperating bodies have retained - as was the case under international criminal law - in the determination of the applicable law, defining the offences, sanctions, procedural rights and duties. Whereas, with respect to international criminal law, many authors have pointed out that this discretion does not go well with the frame of the sovereign nation state as the vehicle to hold its criminal justice actors to account, the situation in the EU is that, while the EU-narrative for crime control has become transnational, the focus with respect to due process remains national. It thus appears that the relationship between the said discretionary margins and considerations of due process is

\footnotetext{
83 Mitsilegas, supra note 12, p. 176-180, 183-184.

84 M. Luchtman \& R. Widdershoven, 'Het Nederlandse strafrecht in de ban van het Unierecht', Ars Aequi (2018), p. 873-889.

85 S. Schmidt (ed.), Mutual recognition as a New Mode of Governance (Routledge 2008).
} 
not recognized in official EU discourse, thus taking for granted the opportunities to, provocatively spoken, 'rule with law' by the cooperating authorities.' ${ }^{86}$

Indeed, the significance of the aforementioned issues is usually downplayed by the proponents of the equivalence model. Under a narrative of equivalence, the discretionary margins do not endanger per se the rule of law in a transnational setting. Mutual 'coordination' and 'consultation' as such, after all, do not bring about interferences with one's fundamental rights. That only happens in a later stage, in the legal order that executes a certain act or commences a procedure. Consequently, that legal order is legally accountable and needs to offer redress, where appropriate. The standards that that legal order applies are considered as 'equivalent' and must in any case, where EU law is applicable, meet those of the Charter. As considerable effort has been put in the strengthening of equivalent safeguards, there can be no relevant issue of forum shopping, laundering of evidence, or circumvention of safeguards.

This position, however, does not take sufficient account of the concept of EU citizenship and the concept of an Area of Freedom, Security and Justice that fosters free movement of persons (not necessarily citizens) in combination with measures to control crime. Free movement of persons as mentioned in Art. 3 (2) TEU and the degree of discretion that the current forms of cooperation entail do not go along well. To demonstrate this position, reference must be made to the role that fundamental rights take up in the setting of national criminal justice. Those rights promote 'agency' for individuals (not only citizens) in at least two ways; they offer legal certainty and they offer legal protection. ${ }^{87}$

Legal certainty is offered by enabling individuals to assess the consequences of their actions - criminal prosecution and, possibly, sanctions - prior to the commission of an offence ${ }^{88}$ or, certainly once charged, when they get involved in criminal proceedings, so that they can determine their defence strategy. ${ }^{89}$

86 B. Bowling \& J. Sheptycki, 'Global policing and transnational rule with law,' 6 Transnational legal theory (2015), p. 141 at p. 146 write: 'These agents act in conditions of low visibility, act with considerable discretion and are largely unregulated by any superordinate form of authority.' See also Meyer, supra note 67; J.P. Brodeur, The policing web (ouP 2010); B. Loftus, Police culture in a changing world (Clarendon/oup 2012); R. Reiner, 'Police and policing,' in: M. Maguire, R. Morgan, R. Reiner (eds.), The Oxford handbook of criminology (OUP 2007).

87 Obviously, fundamental rights do much more than that (guaranteeing fairness, proportionality, etc), but the focus in this contribution is on these two elements. $C f$. M. Groenhuijsen \& G. Knigge, Afronding en verantwoording - Eindrapport onderzoeksproject Strafuordering 2001 (Kluwer 2004), p. 24-28.

88 Nullum crimen, nulla poena sine lege; arts. 49 CFR and 7 ECHR.

$89 \quad$ Nullum judicium sine lege; arts. 47 and 48 CFR and 6 ECHR. 
Rights offering legal protection in criminal proceedings are typically those protecting one's liberty, privacy or property. The requirement that investigative measures that interfere with these rights must have a decent basis in the law then primarily aims to offer individuals an adequate indication of the scope of governmental powers. ${ }^{90}$ Obviously, this is not to allow individuals to anticipate the application of these measures, as that would render them ineffective. Instead, the law primarily offers ex ante guidance for and expost review of investigative and prosecutorial acts.

In the specific setting of the Area of Freedom, Security and Justice, the aforementioned discretionary margins have introduced another, legally recognized dimension to the notion of 'arbitrariness'; said discretionary margins interfere with the concept of free movement of persons. It makes sense to assume, after all, that as EU law promotes 'transnational agency' through the free movement of persons, the criminal law consequences of such movement must also be clear, at the least where they interfere with the fundamental rights of those persons. Yet because the relevant offences, sanctions, procedures, rights and duties are still largely determined by national law, the same must go for the circumstances that trigger the applicability of the laws of the specific legal order(s) in play. ${ }^{91}$

When it comes to legal certainty, the status quo, however, presents a picture wherein individuals are required to deal with the (potential) application of a multitude of laws - even the ones they cannot know at the time of action - and with the divergences and contradictions that they still entail, despite the narrative of equivalence. Those individuals need to understand, as said, that the same conduct may lead to a custodial sanction of a maximum of three years in one jurisdiction and to a minimum sanction of at least four years in another. Moreover, those individuals must take account of the fact that their relationship with legal counsel may be protected by professional privilege in one jurisdiction, but not in another. Of course, those individuals are still able to determine their position with reference to the law where they stand trial, but it is an anomaly to deny that the exercise of these rights - and the design of the overarching defense strategy - must also take account of the actions and procedures that (may) take place elsewhere, even to the point where the

9o $\quad$ ECtHR 2 August 1984, Malone v. United Kingdom, appl.no. 8691/79, para 67.

$91 \quad C f$. A. Marletta, 'Forum choice in the area of Freedom, Security and Justice', in Ligeti \& Robinson, supra note 48, p. 140 at p. 156; Ambos, supra note 11, p. 127-128, 231; M. Böse (et al.) (eds), Conflicts of jurisdiction in criminal matters in the European Union (Nomos 2014), p. 109-124; Mitsilegas, supra note 12, p. 93-94; M. Luchtman, 'Towards a Transnational Application of the Legality Principle in the EU's Area of Freedom, Security and Justice?', 9 Utrecht Law Review (2013), p. 11-33. 
safeguards in the eventual forum state become illusory. The results of criminal investigations - documents obtained from legal counsel, for instance - are after all likely to be shared between the cooperating and coordinating bodies. Where national borders no longer play a role in the narrative, criminal procedures in different jurisdictions - including the rights, duties and safeguards they intend to offer - into the same set of facts become 'interlinked'. The determination of criminal offences and sanctions, the exercise of defence rights and the determination of a coherent defence strategy must consequently take account of (interferences with) rights in other jurisdictions.

Legal protection is equally hampered in transnational investigations, certainly under those forms of cooperation wherein the cooperating authorities act as a functional unity of multiple agencies, with comparable tasks and in the pursuit of a common goal, i.e. a series of (related) national criminal investigations. Although these authorities remain a part of their own legal order from an institutional perspective, functionally their actions and procedures are inextricably linked, both in substance, time and space. ${ }^{92}$ Their coordinating work, wherein many important decisions (the determination of the applicable law, for instance) are taken and wherein the results are consequently shared, clearly hampers individuals to obtain an adequate indication of the scope of investigatory powers. Digital evidence is easily accessible from multiple jurisdictions, yet often under very different conditions. The mutual comparison of those conditions by the authorities is then by no means merely 'coordinative action. The protection of the right to privacy in one jurisdiction has become linked to that in another.

Some of the existing instruments indeed recognize this. The European Investigation Order directive has introduced the rule that the issuing of an EIO is allowed only if 'the investigative measure(s) indicated in the EIO could have been ordered under the same conditions in a similar domestic case. ${ }^{93}$ This rule clearly aims to avoid forum shopping. ${ }^{94}$ But it also reflects a one-dimensional approach to cooperation, wherein one party only seeks assistance from another. It does not adequately tackle transnational, interlinked investigations,

92 I have deliberately used this phrasing. As said before, it plays an increasing role in the case law of the ECtHR (in the national setting) to articulate that defence rights may not to be hampered by the interplay between administrative and criminal procedures; $\mathrm{cf}$. the cases of Chambaz/Switzerland, supra note 64 (nemo tenetur) and of $A$ and B/Norway, 15 November 2016, appl.nos. 24130/11 and 29758/11 (ne bis in idem). The same logic can be applied in a transnational setting. Under the substantive legality principle of Art. 7 ECHR, the problems also come back in the aforementioned case of Camileri/Malta, supra note 61.

94 That is also the aim - but to a more limited extent (limited to ex ante judicial authorizations) - of Art. 31 of the EPPO regulation, supra note 29. 
within the framework of joint teams, networks, EU agencies, et cetera. Only the Revised Eurojust 'Guidelines for deciding 'Which jurisdiction should prosecute?' (2016) contain some guidance on this: 'The existing legal framework, including obligations and requirements that are imposed in each jurisdiction, should be considered as well as all the possible effects of a decision to prosecute in one jurisdiction rather than in another and the potential outcome in each jurisdiction. However, judicial authorities should not decide to prosecute in one jurisdiction rather than another simply to avoid complying with the legal obligations that apply in one jurisdiction but not in another. Though this provision signals the same concerns as expressed here, it goes without saying that its operation is virtually impossible to apply or control.

\subsubsection{A Composite Legal Order: the importance of Legislation at EU Level}

Whereas the scope of fundamental rights is thus still defined nationally, transnational investigations have the inherent capacity to hinder their full application, as those rights and the interests that they protect are in constant interaction with actions that take place or may take place in other legal orders. In the absence of a European framework, the default position is that individuals need to find their way amongst all of the potentially applicable legal systems, even when their application is not self-evident or when their cumulative application produces contradictory results. Clearly, that interferes with the concept of free movement of persons.

The default is confirmed by the one case I could find on this problem. Akzo/ Akcros deals with the diverging standards on legal professional privilege in national and EU competition law in light of the rights of defence and the principle of legal certainty. Whereas UK law does cover in-house lawyers under the privilege, EU law does not. UK and European competition authorities, however, work closely together for the purposes of enforcing both EU and national competition laws. To what extent, then, can the protection of communications with enrolled in-house lawyers depend on whether investigations are conducted by the Commission or by a national competition authority?

Both the Advocate-General ${ }^{95}$ and the Court do not go along the line advocated here. In an approach reminiscent of the ne bis in idem cases in competition law, ${ }^{96}$ the latter held that 'restrictive practices are viewed differently by European Union law and national law. Whilst Articles 101 TFEU and 102 TFEU view them in the light of the obstacles which may result for trade between the

95 Opinion A-G- Kokott 29 April 2010, Case C-550/07 P, Akzo/Akcros.

96 Supra note 75 . As was said there, the ECJ takes a similar approach in cases of concursus. 
Member States, each body of national legislation proceeds on the basis of considerations peculiar to it and considers restrictive practices solely in that context (...). In those circumstances, the undertakings whose premises are searched in the course of a competition investigation are able to determine their rights and obligations vis-à-vis the competent authorities and the law applicable, (...). The undertakings can therefore determine their position in the light of the powers of those authorities and specifically of those concerning the seizure of documents. ${ }^{97}$ Consequently, although the raised 'objection expresses an entirely understandable concern, it is none the less untenable from a legal point of view, the Advocate-General noted. ${ }^{98}$ The EU judiciary may be willing to interpret fundamental rights in light of their transnational setting, but only where it can build on specific EU legislation, as was the case for $n e$ bis in idem (Schengen), but not - with regard to legal privilege, ne bis in idem or concursus $^{99}$ - at the interface of national and European competition law.

The situation indeed appears to be different in criminal law, where the protection of national sovereignty is prominent on the agenda, yet - paradoxically the competences for justice integration appear stronger than in competition law. The best illustration of this is, as said, the Schengen case law, wherein the Court of Justice has turned the concept of free movement of persons into a narrative for 'transnational agency' for individuals, alongside nation-states. That narrative not only prevents that someone is confronted with multiple claims of jurisdiction on account of his having exercised his right to freedom of movement, ${ }^{100}$ but also promotes a person's future movement within the common justice area. ${ }^{101}$ The Schengen case law thus conveys the message that if individuals are truly to be recognized as autonomous agents alongside nationstates in the European legal order, they need to be able to cope with the criminal law consequences of the free movement of persons.

This, in turn, begs the question of why the same narrative is not used as an inspiration for new legislative instruments, based on, particularly, Arts. 82 and 83 TFEU. Those instruments would help to strengthen other fundamental rights (not only ne bis in idem) in order to further the concept of 'transnational agency', but also to promote the rule of law in transnational investigations. Such a legislative agenda would have to:

1. allow individuals - not only EU citizens - to adequately assess, in due time, the full consequences of the free movement of persons in terms of

\footnotetext{
97 ECJ 14 September 2010, Case C-550/07 P, Akzo/Akcros, para 103-104.

98 Opinion, para 132.

99 ECJ 3 April 2019, Case C-617/17 (Powszechny Zakład Ubezpieczeń na Życie), ECLI:EU: C:2019:283.

$100 \quad$ ECJ, Kossowski, supra note 74, para 44.

101 Ibid., para 45.
} 
the applicable offences, sanctions, but also the applicable rights and duties in criminal procedures;

2. allow for an adequate indication of the scope of governmental powers in interlinked transnational investigations;

3. prevent unnecessary barriers to the future free movement of individuals, by continuing, uncoordinated criminal investigations in multiple jurisdictions.

The question is to which extent these goals can be achieved by further harmonizing individual criminal laws across EU states. Rather, such goals seem to require strong and independent actors in the sphere of criminal justice, ${ }^{102}$ coordination of laws and procedures, as well as adequate judicial protection and accountability. That is why particularly regulations on the choice of forum and transnational legal protection, ${ }^{103}$ linked to the mutual admissibility of evidence urgently require legislative attention. It is imperative, after all, in an Area of Freedom Security and Justice not only to have an eye for issues of crime control, but also for the legal position of the individual.

Advanced European models for transnational cooperation and the approximation of criminal law and procedure go in hand in hand, and rightly so. The frame of a composite legal order, in my view, fits best the changes that have been introduced in transnational cooperation and the future plans that have been announced. It presents an image wherein not only the judicial, but also the executive branches of the different legal orders are in direct contact to realize common goals. Dialogues exist not only between the national courts and the ECJ, but are also encouraged, as an integrated part of the cooperation schemes, between police and prosecutorial bodies and between courts in a horizontal, transnational setting. It is certainly not unreasonable to expect that, as a result of this, cooperating authorities will start to set joint actions, policies and priorities, under processes of mutual consultation and coordination.

It is impossible to promote these processes and models, while simultaneously proceeding on a basis of 'mind your own business', when it comes to the operation of the individual national criminal justice systems. The EU is right to

\footnotetext{
102 Supra note 43.

103 Cf. the prosopal for a horizontal, transnational preliminary reference procedure by Böse; Martin Böse, 'Die Europäische Ermittlungsanordnung - Beweistransfer nach neuen Regeln?', ZIS 4 (2014), 152-164 (160).
} 
claim and exercise competence over national criminal justice systems. The dominant view on the relationship between transnational cooperation and approximation is, however, one of equivalence. The introduction of a common basis of offences, sanctions, and, particularly, defence and victims' rights, combined with the effects of EU law in national legal orders are intended to strengthen the foundations for mutual trust.

The current approach requires, in my view, modifications. The focus on the improvement of the individual legal orders of the EU Member States, obfuscates the issue of the discretionary margins at the interface of the legal orders of the EU States. From a normative angle, and certainly in criminal justice, these processes need guidance as they are able to produce unforeseeable and uncontrollable results. Meanwhile, recent case law of the ECJ and national courts have made it abundantly clear that the judiciary is not apt to take up the problems identified here. The message from the ECJ's case law is that, although it has expanded the scope of EU law (and the Charter) in Akerberg Fransson far into the domain of national criminal justice, ${ }^{104}$ it is also aware of the composite nature of the European legal order. Though it has consistently confirmed the wide applicability of the general principles of EU law, including the Charter, it has made a clear attempt to ease the tensions with national courts. In the absence of specific EU legislation, it has recently showed its willingness to lower the standards on, for instance, the principle of effectiveness (Taricco $I I)^{105}$ or fundamental rights (Menci). ${ }^{106}$

This is different where EU law is present, as is clear from the Schengen case law on the ne bis in idem principle and from Melloni. ${ }^{107}$ The latter case has been criticized because it hinders national legal orders in the application of their constitutional standards. ${ }^{108}$ But Melloni is precisely the wrong case to make that argument. Rather, it begs the question as to why the application of those national standards would be still necessary. It must be noted that within a situation of full harmonization of dealing with judgments in absentia in EAW cases, the standards of the revised Framework Decision on the European Arrest Warrant were already beyond the thresholds of 'Strasbourg', 109 whereas Spain was not the trial state in this case. Why then, would there be a need to

\footnotetext{
104 ECJ 26 February 2013, Case C-617/10, Åkerberg Fransson.

105 ECJ 5 December 2017, Case C-42/17, M.A.S. and M.B.

106 ECJ 20 March 2018, Case C-524/15, Menci.

107 ECJ 26 February 2013, Case C-399/11, Melloni.

$108 C f$. W. van Ballegooij \& P. Bárd, 'Mutual recognition and individual rights', 7 New Journal of European Criminal Law (2016), p. 457-459.

109 V.H. Glerum, De weigeringsgronden bij uitlevering en overlevering (WLP 2013), p. 233-238, $272-273$.
} 
apply the even higher Spanish constitutional standards, to the detriment of the operation of the EAW-scheme? The effort that is thus put in warding-off $\mathrm{EU}$ law, comes at the expense of a system of transnational law enforcement that not only promotes effective law enforcement cooperation, but, ultimately, also fundamental rights protection.

The foregoing leaves me to conclude with two points. First of all, a composite legal order requires all state branches to adopt an open attitude. I cannot escape the impression that some of those actors - legislators and courts - are primarily concerned with warding-off $\mathrm{EU}$ influence, at the least in cases where they are not a requesting (or issuing) party. That brings me to my second point. Such openness is a vital condition for improving legal certainty and legal protection in transnational criminal justice, as adaptations to national criminal justice systems will be necessary. New instruments for transnational cooperation need strong encouragement, but also guidance by the legislator, at the EU level and the national level. This is, par excellence, a matter that Member States cannot deal with individually. Yet the EU cannot realize this task when national legal orders do not open up.

This is not the place to lay out in detail the design for such new legislative proposals. It suffices to refer to the many instruments and policy options that have already been proposed in the past, all of them with pros and cons. Yet these proposals have repeatedly been put aside as 'unrealistic', 'unnecessary', or 'utopian'. The point at issue in this contribution is that it is too easy to dismiss these proposals merely on that basis. The terminology, competences, instruments and institutions that have been put in place or were reinforced by the Treaty of Lisbon beg the question of why the EU - and particularly its policy makers and legislators - does not place its own narrative on the foreground, instead of playing down or even ignoring the importance of some of the key concepts of its own legal order, including transnational agency for individuals, fundamental rights and, arguably still imperfect, ${ }^{110}$ democratic representation at the EU level for EU citizens. Topics that particularly deserve attention are, in my view, regulations for forum choices, the harmonization of procedural safeguards for covert or coercive measures, the admissibility of evidence and the organization of judicial review in composite procedures. All of these are necessary to protect the interests of individuals on the European territory - whether they are 'citizens' or not - against arbitrary interferences with their position, but also to provide the law enforcement community with the guidance and clarity it needs to perform its tasks.

110 According, at the least, to the German Federal Constitutional Court, supra note 21. 